\title{
INDONESIA'S MID-LIFE CRISIS, 1978-1995
}

\section{Audrey R. Kahin}

In mid-1978 I joined Ben Anderson in editing the journal Indonesia at a time when research on post-revolutionary Indonesia was perhaps at its lowest ebb. The Suharto regime had been in power for well over a decade, and was, after a brief period of relative tolerance, increasingly clamping down on internal dissent and foreign criticism. It had become ever more difficult for American and other foreign scholars of modern history and politics to obtain visas to conduct research in Indonesia, although, strangely enough, anthropology students, along with scholars in language and literature, had much less difficulty.

\section{Indonesian Studies at Cornell}

This situation stood in sharp contrast to that in the 1950s and early 1960s. In 1954, with support from the Ford Foundation, George Kahin founded the Cornell Modern Indonesia Project (CMIP), and from then until the change of regime in 1966, graduate students and other scholars at Cornell enjoyed unusual access to Indonesia. Their favorable treatment was largely a result of the friendships and connections Kahin had formed with many of Indonesia's leaders in the course of carrying out his dissertation research during the revolution, when he spent months in the republic's capital of

Audrey R. Kahin was editor of Indonesia from 1978 to 1995. As a scholar and historian, her publications include The Historical Dictionary of Indonesia, third revised ed. (Lanham \& London: Scarecrow Press, 2015); Islam, Nationalism, and Democracy: A Political Biography of Mohammad Natsir (Singapore: NUS Press, 2012); and Rebellion to Integration: West Sumatra and the Indonesian Polity, 1926-1998 (Amsterdam: Amsterdam University Press, 2000). 
Jogjakarta. ${ }^{1}$ His friendly ties with many of the leading figures in the Republican government at that time had been cemented when, in December 1948, during the Dutch attack on the city, he, along with these Indonesian leaders, was arrested and imprisoned by the Dutch military, though he was held for only a few days.

The period of good relations between Cornell and Indonesia ended after the bloody regime changeover in the mid-1960s, when tension arose between Cornell and the "New Order" of President Suharto. In 1966, Ben Anderson, Ruth McVey, and Fred Bunnell, all current or former graduate students in government at Cornell, wrote a tentative analysis of the events surrounding Indonesia's 1965 coup ("Gestapu," Gerakan Tiga Puluh September), based largely on the wealth of Indonesian newspaper holdings lodged in the Cornell library. By 1970, knowledge of this so-called "Cornell Paper" ${ }^{\prime 2}$ had become widespread in Indonesia, and the Suharto government, as well as some American officials, attempted to persuade the authors to retract their statements regarding the coup's origins, and called on faculty members at Cornell to disown the authors' right to publish their findings. When this did not happen, relationships worsened.

In 1972, Ben Anderson was banned from Indonesia, ${ }^{3}$ and three years later, in the fall of 1975, Lt. Gen. Ali Murtopo, deputy chief of President Suharto's intelligence service, and Maj. Gen. Benny Murdani, head of intelligence in Indonesia's department of defense, led a delegation to Ithaca to give scholars at Cornell a full briefing on the Indonesian military's version of the coup and its background. ${ }^{4}$ (It was during this visit that George apparently prevailed on General Murdani to allow my own application for a research visa for Indonesia, which had been in abeyance for several months, finally to be approved.) When George visited me in Jakarta the following year, General Murtopo, in a renewed effort to persuade him to disown his former students, offered to set up a well-funded, joint project on the Indonesian Revolution between Cornell and the Center for Strategic and International Studies (CSIS) in Jakarta. This offer George refused, and eventually all attempts at compromise broke down.

From then on it became increasingly difficult for scholars from Cornell (and, indeed, any other overseas university) to conduct independent research on Indonesia's modern history and politics that might reach conclusions not in accord with the Jakarta government's viewpoint. George and I were blacklisted between 1976 and 1991, and my applications in 1981 and 1985 to carry out historical research on West Sumatra in the 1920s and '30s were firmly rejected. ${ }^{5}$ Many other American scholars, especially in

\footnotetext{
${ }^{1}$ His personal account of these months appears in his memoir; see George McT. Kahin, Southeast Asia: A Testament (London \& New York: Routledge, 2003), 17-115.

2 Published by CMIP in 1971 in its Interim Report series under the title "A Preliminary Analysis of the October 1, 1965, Coup in Indonesia," available online at http://cmip.library.cornell.edu/cgi/t/text/text-idx?c= cmip;cc=cmip; view =toc;subview=short;idno=cmip052, accessed September 8, 2015.

${ }^{3}$ Anderson was not allowed to return until 1998, after the fall of Suharto. Ruth McVey and Fred Bunnell were also briefly barred from entering Indonesia.

${ }^{4}$ A year later another group of the Indonesian military brought over a pile of materials regarding the coup to be deposited in Cornell's library.

${ }^{5}$ I did manage to visit Indonesia for a couple of months in 1985 when, in the middle of a large group of tourists, George and I entered the country via the Medan airport, which at that time had not yet been computerized.
} 
the fields of modern history and politics, faced similar barriers in their efforts to conduct their research.

\section{History of the Journal Indonesia}

The Ford Foundation renewed its funding of the Cornell Modern Indonesia Project in 1962, and over the subsequent decade the focus of CMIP's research spread beyond politics and government to Indonesia's prerevolutionary and revolutionary history, its culture, and recent and current international relations. In April 1966, in addition to the "interim reports," monographs, translations, and bibliographies it published, which by then numbered about forty, CMIP brought out the first issue of the twice-yearly interdisciplinary journal Indonesia. Under CMIP's auspices, Ben Anderson, still at that time a graduate student in Cornell's government department, was largely responsible for launching the journal, assisted mostly by his fellow graduate students in the Southeast Asia Program.

At the end of 1972, when the last of CMIP's research funds ran out, the Ford Foundation agreed to CMIP's husbanding its residual inventory of publications and using the proceeds of their sale as an ongoing revolving fund for continuing the various publication series. However, this revolving fund was not large enough either to support all the editorial and distribution costs for these publications, or to finance the journal Indonesia. Recognizing this, Cornell's Southeast Asia Program (SEAP) in 1974 agreed to shoulder the editorial and distribution costs of Indonesia and provide a subvention to keep it afloat. When SEAP assumed these costs, which had previously been met by CMIP, the journal became an official part of the program's publications, a fact that Indonesia's editors needed to keep in mind when deciding the range and scope of what would be published.

SEAP also agreed to provide funding for a part-time professional editor to work with Ben Anderson in producing the journal. Prior to that time, editorial tasks were largely in the hands of an ad hoc group of graduate students and young faculty members who volunteered their expertise in helping Anderson put together and publish the journal. After 1974, the first editors to share the editorial tasks were Marty Hatch, who was then completing his graduate studies in Cornell's Music Department, and his wife, Susan. In 1976, Judy Ecklund, a graduate student in Southeast Asian anthropology, succeeded them as Ben's co-editor until I took over in October of $1978 .{ }^{6}$

\section{State of the Field in 1978}

By 1978, many other major shifts had occurred in the field of Southeast Asian studies at Cornell and more generally in the United States. Since the early 1970s, as a

\footnotetext{
${ }^{6}$ Throughout most of my time as editor I relied to a great extent on Dolina Millar, who contributed far more to the success of the journal and all our other publications than her title of "Business Manager" would indicate. I also relied on Roberta Ludgate, who, before the age of computers, transformed a messy typescript into publishable text, and on Hazel Garvin, who ably managed the distribution office. Notable among the assistant editors, who took over when I was abroad, was Donna Amoroso, who later established almost single-handedly the multi-lingual Kyoto Review of Southeast Asia, a remarkable on-line journal that is one of a kind and of which she was founding editor.
} 
result of the Vietnam War, Indochina had largely replaced Indonesia as the major area of specialization for graduate students in Cornell's Southeast Asia Program. Since the inception of SEAP, Thailand had always been almost as attractive to graduate students as Indonesia, especially for those in the field of anthropology, and by the end of the decade the Philippines also became a major focus of student interest, especially as Ben Anderson himself, banned from conducting research in Indonesia, now centered his major research and teaching on those two countries. With Indonesia no longer the major focus of Southeast Asian studies (not only at Cornell, but throughout the United States generally), an increasing proportion of the scholars writing on modern Indonesia were coming from outside the United States-from Europe, Indonesia, Japan, and especially Australia.

Also by the middle 1970s, it was becoming clear that in political science and economics, and to a lesser extent in history and anthropology, there was a move toward what Ben has described as the "professionalization and technicalization"7 of the disciplines and away from area specialization. This coincided with the university's organization becoming more complex. In 1965, the Center for International Studies (CIS) had been established as an umbrella division for international programs at Cornell, and in the early 1970s SEAP was subsumed under this umbrella. Along with this university-wide shift away from area studies, Southeast Asia studies also witnessed "a dramatic shift from an overwhelming majority in the traditional liberal arts 'lower campus' disciplines in the earlier period, towards the currently more nearly equal numbers in the more applied or "upper campus' disciplines." 8 These shifts were reflected in the number of articles in these disciplines submitted to the journal. At that time, with little likelihood of being able to carry out their research in Indonesia, few American graduate students chose modern Indonesian politics as their field of study, and Indonesia's editors were receiving few submissions in this field. So, to some extent, the balance of articles in the journal began to mirror the changes in emphasis in the various disciplines.

At the time I took over as co-editor of the journal, the original team of Indonesia's editors-contributors had all, with the exception of Jim Siegel and Ben himself, moved on from Cornell. Consequently, it was more difficult to call directly on scholars at Cornell either to produce articles for the journal, or to prevail upon their students and colleagues to contribute. Moreover, with the general decline of research on Indonesia in the United States, few unsolicited manuscripts were being submitted and for the first several years it was a constant battle to find enough good articles to fill Indonesia's pages. At the same time, in 1978, I had been charged with bringing more professional standards to the journal, as outside authors were complaining that unless it was a peerreviewed journal, the articles they wrote for it carried little weight in their academic departments. So in line with other academic journals, Indonesia began to require that, before publishing any article, it would need to receive favorable reviews from two independent referees.

\footnotetext{
7 Interview with Ben Anderson, October 23, 2007.

${ }^{8}$ Memo, "Cornell Southeast Asia Program Evaluation," by David Szanton, December 3, 1981.
} 


\section{Issues of Indonesia, 1978-1995}

As a result of these many factors, the character of Indonesia underwent a number of changes during the years following 1978, with greater emphasis now being placed on the fields of colonial and precolonial history, anthropology, literature, and the arts, rather than on contemporary politics. Although we received fewer submissions dealing with current Indonesian events, during these years we nevertheless were able to publish twenty-four articles that can be described as "political," including a number of essays tackling controversial issues, focusing both on the Suharto military government and on the change of regime in 1965. In addition, "Current Data on the Indonesian Military Elite," officially compiled by the editors but largely the work of Ben Anderson and Takashi Shiraishi, appeared at least every other year during this period. Indonesia also published a number of contemporary documents dealing with such issues as the students' protest movements and East Timor. (At the same time, the Cornell Modern Indonesia Project, which remained independent and still produced approximately one to two publications a year, was able to bring out several monographs on controversial issues that other publishers were reluctant to publish. Notable among these was the excellent study of Indonesia's military regime-Suharto and His Generals: Indonesian Military Politics, 1975-1983 |1984], written by the Australian journalist David Jenkins. ${ }^{10}$ )

During these years, however, the major emphasis of the articles in Indonesia was on less controversial topics. Of the seventy-five articles published on what can broadly be described as "Indonesian history," more than two thirds dealt with the colonial and precolonial periods (for which most if not all of the research could be conducted in libraries in the Netherlands), and about a dozen dealt with the Japanese occupation and the anticolonial revolution. Only a handful focused on post-independence Indonesia.

As it was relatively easier for students of anthropology to conduct research in Indonesia than it was to study such disciplines as Indonesian politics or history, we received a large number of submissions in anthropology. During my tenure as editor, Indonesia published thirty-five articles on anthropology, exceeding the number published in the broad fields of arts, language, and literature (thirty-two) - fields in which scholars could also still conduct their research with relative ease. In addition to publishing articles on Indonesian literature, we continued Indonesia's practice of bringing out a substantial number of English translations of essays and short stories by Indonesia's major writers, including most notably Pramoedya Ananta Toer and Idrus. At the same time, Indonesia's contents began to reflect the "dramatic shift," noted above, of larger numbers of Cornell students interested in Indonesia coming from the agricultural or "upper campus" rather than from the Arts Quad.

The years between 1978 and 1995 witnessed the deaths of most of the first generation of independent Indonesia's major political leaders, and this was reflected in Indonesia's pages. "In Memoriam" articles appeared on many of Indonesia's

\footnotetext{
9 Among these were Sjafruddin Prawiranegara's "Pancasila as the Sole Foundation" (vol. 38, October 1984), Ben Anderson's "I low Did the Generals Die" (vol. 43, April 1987), and Edward Aspinall's "Students and the Military: Regime Friction and Civilian Dissent in the Late Suharto Period" (vol. 59, April 1995).

${ }^{10}$ Also in this category are Dwight King's "White Book" on the 1992 General Election in Indonesia (1994) and Tim Kell's The Roots of Acehnese Rebellion (1995). All three titles are available at: http://cmip.library. cornell.edu/c/cmip/browse.html.
} 
revolutionary leaders, from Indonesia's first vice president, Mohammad Hatta, in 1980, to the article marking the death of Indonesia's first prime minister, Mohammad Natsir, in 1993. ${ }^{11}$ These In Memoriam articles not only marked the passing of major Indonesian political leaders, but also that of foreign scholars of Indonesia, such as Christiaan Hooykaas (1980), John Echols (1982), and Akira Nagazumi (1988), as well as Indonesian friends and scholars, such as Siauw Giok Tjan (1982), Soemarsaid Moertono (1987), Paramita Abdurrachman (1988), and Jo Kurianingrat (1994).

Reviews of books on Indonesia occupied little space during the journal's early years, and this continued for a while after 1978, with a total of only five reviews appearing in the years between 1978 and 1985. Thereafter, as the number of scholarly studies focusing on Indonesia multiplied, we began to publish a larger number of book reviews, until by the mid-1990s four or five reviews were appearing every year.

Despite the decline in Indonesian studies in the United States, throughout the years between 1978 and 1995 about half of the articles appearing in Indonesia still came from US universities (138 out of 266), although those written by scholars at Cornell decreased from twenty-two in the period 1978-83 to twelve in the years 1989-94. About a fifth of the articles came from Australia in the years between 1978 and 1983 (fifteen out of seventy-four), dropping to about a tenth in 1989-94 (ten out of ninetysix). This decline was balanced by an increasing number of essays published by scholars in Europe, with the number of articles from the Netherlands growing from three in the 1978-93 period to eighteen between 1989 and 1994. ${ }^{12}$ The number from Indonesia declined from ten in the first five-year period to four between 1989 and 1994.

The Suharto regime had only three more years in power when I resigned as editor in 1995. It had done much to stifle scholarly research on modern Indonesia and had blocked the development of contemporary Indonesian studies. It would take several years before the easing of research restrictions would enable more foreign scholars to pursue their research interests in the emerging democratic state. Indonesia survived its lean years and was then able to reassume its role of publishing some of the best scholarship on contemporary Indonesia, the role envisioned by its founders more than thirty years earlier.

11 Other political leaders memorialized in Indonesia's pages include Sutomo (1982); Mohamad Roem (1984); Adam Malik (1985); and Hamengkubowono IX, Maria Ulfah Soebadio, and Sjafruddin Prawiranegara (all in 1989)

12 There were fourteen articles from France in the 1989-94 period compared to two in the previous five years, but this was largely because a Special Issue of Indonesia in April 1994 consisted entirely of translated articles from the French journal Archipel. 